\title{
Can Youth Quotas Help Avoid Future Disasters?
}

\author{
Wallimann-Helmer, Ivo
}

\begin{abstract}
In this paper I argue for the following conclusions. First, quotas are not normative goals in themselves but only a means to reach non-discriminatory selection procedures. Second, in a democracy quotas are most plausibly used as a means to fill offices in those bodies which have a major impact on how well interests or discourses are translated into policy. Third, quotas for the young can be justified since, due to demographic development, their discourses tend to be marginalized. Fourth, youth quotas cannot be a means to ensure long-term policy-making, but they can enhance legitimacy of long-term impacts from policy decisions taken today.
\end{abstract}

DOI: https://doi.org/10.1007/978-3-319-13431-4_5

Posted at the Zurich Open Repository and Archive, University of Zurich

ZORA URL: https://doi.org/10.5167/uzh-101443

Book Section

Accepted Version

Originally published at:

Wallimann-Helmer, Ivo (2015). Can Youth Quotas Help Avoid Future Disasters? In: Dimitrijoski, Igor; Godli, Petter; Mason, Antony; Munius, Bettina; Tremmel, Jörg. Youth Quotas - And other Efficient Forms of Youth Participation. Heidelberg: Springer, 57-75.

DOI: https://doi.org/10.1007/978-3-319-13431-4_5 


\title{
Can Youth Quotas Help Avoid Future Disasters?
}

\author{
Ivo Wallimann-Helmer
}

University of Zurich, University Research Priority Program for Ethics

[To be published in Jörg Tremmel, Antony Mason, Igor Dimitrijoski, Petter Godli (eds.): Youth Quotas and Other Forms of Youth Participation in Ageing Societies]

Version 30 June 2014

\begin{abstract}
In this paper I argue for the following conclusions. First, quotas are not normative goals in themselves but only a means to reach non-discriminatory selection procedures. Second, in a democracy quotas are most plausibly used as a means to fill offices in those bodies which have a major impact on how well interests or discourses are translated into policy. Third, quotas for the young can be justified since, due to demographic development, their discourses tend to be marginalized. Fourth, youth quotas cannot be a means to ensure long-term policy-making, but they can enhance legitimacy of long-term impacts from policy decisions taken today.
\end{abstract}

Keywords: rigid quotas, weak quotas, affirmative action, equality of opportunity, representation, democracy, short-termism, intergenerational justice

\section{The Problem}

In an insightful comparative study, Peter Vanhuysse showed that many OECD countries, especially developed democracies, score rather badly with regard to the demands of intergenerational justice (Vanhuysse 2013). These democracies not only score badly on factors such as absolute child poverty or child poverty in relation to old-age poverty but also have a bad score on the public debt they leave per child and their ecological footprint. Although this study is comparative and allows for no absolute measures, it shows that democracies tend to favour the interests of older age-groups and have a tendency for unsustainable policy decisions.

If we follow Dennis F. Thompson, these findings can be explained by four more theoretical reasons (Thompson 2010: 18-20). First, there is the human tendency to prefer 
immediate gains to those in the far future. In consequence, it is more probable that policy decisions showing immediate measurable results will be taken in democracy, with a rather short-term perspective. Second, policy decisions should be responsive to the judgements of citizens about the effects of laws on their interests. As a consequence, there is a tendency that a democracy will only accept policies which correspond in at least a minimal sense to the (potentially short-term) interests of the currently living. Third, political power is temporal; short election cycles are necessary to avoid autocracy. Thus, democracies provide an incentive structure favouring short-term policy with immediate gains for the living because these enhance the chance of staying in political power. Fourth, in democracy there is a tendency to favour older age groups and their interests, which leads to a focus on present needs that neglects ensuring similar benefits for the future. This reason can be substantiated empirically. Due to demographic development, the old are increasing their majority in democracies, which leads to the consequence that they have more voting power and are better represented in the political bodies. Accordingly, policy decisions tend to be biased towards the interests of the older members of the population. ${ }^{1}$

In the light of anticipated environmental disasters, especially the impacts of climate change, this tendency of democracy to short-term decisions becomes a problem, since the negative impacts of these decisions will have to be borne by those who today are young (let's say those who are under 25 or 30 years). To counteract this tendency, one can imagine three different ways to change decision-making processes in democracies, either to ensure more sustainable policy-making or to shift political power from the old to the young. First, one could introduce institutions to represent future generations. Thompson, for instance, proposes trustees to secure the possibility of democracy in the future. The role of these trustees would

\footnotetext{
${ }^{1}$ I draw here on Vanhuysse 2013: 23-24. Interestingly enough, demographic development and an increasing number of older people have not only negative effects. As Dyson 2012 shows, the ageing of the citizen body tends to increase democratization.
} 
be either to fill specific seats in the legislative assembly or to be part of a commission. In both cases, their task would not be to propose new policy but to voice the interests of future generations and to challenge those policy decisions which seem to undermine the democratic capacity of future generations (Thompson 2010: 26-30). ${ }^{2}$ Second, the voting system could be adjusted. As a consequence of his research, Vanhuysse argues in line with others that the time might have come to introduce proxy votes for parents. Each parent should receive an additional half-vote per child (Vanhuysse 2013: 41-43). ${ }^{3}$ Such a system would shift the voting power from the old to the young and might have as an effect that political parties would try to change their programmes in a way to cope better with family interests and perhaps with sustainable policy-making. Third, one could introduce quotas for the young in representative, executive, judicative or administrative bodies in democracy.

Analysing each of these three ways to counter-act democracy's tendency to short-term policy-making needs a paper length discussion. In this paper, I will only be concerned with the last of the three proposals. My aim is to answer the following two questions. 1. Can quotas be justified as a democratic means to secure better representation of the interests of the young? 2. Are youth quotas an effective means to ensure that decisions are taken with the degree of attention to environmental sustainability issues that they demand? I will answer the first question with a qualified "Yes!" Although quotas may be justified to secure proportional political representation of the young in the wake of demographic development, what I call "political affirmative action programmes" - the weakest form of quotas - are better suited to securing the political power necessary for the young to decide on the future they will have to face. ${ }^{4}$ The second question I will answer with a qualified "No!" Since there is a human

\footnotetext{
${ }^{2}$ Another example to understand the role of representatives of future generations is provided by Ekeli 2005.

${ }^{3}$ For a critical normative assessment of this and other proposals to secure intergenerational justice in democracy, see van Parijs 1998.

${ }^{4}$ I explain in Section 3 what I understand by "political affirmative action programmes". In short, they select candidates from disadvantaged social groups for offices if they gain equal or similar voting power, rather than a candidate from an advantaged social group.
} 
tendency to favour immediate gains over ones that are more distant in time, it is implausible to believe that the young will fare better than the old. But ensuring more adequate representation of the young enhances the legitimacy of the long-term impacts of policy decisions taken today. Those who have to face the consequences should be appropriately included in the decisions taken.

To answer my two questions more fully, we first need to know what quotas are and what they can achieve. In the second section, I will introduce quotas as they have been discussed in political theory with regard to the principle of equality of opportunity. I argue that quotas can only be justified as a means of reaching less discriminatory selection procedures for social positions, but that they cannot be justified as a normative goal in themselves. We also need to be clear about the role quotas could probably serve within a democratic institutional framework. In the third section, I show under what conditions quotas can be justified in democracy as a means of achieving proportional representation of all the different interests in society. These clarifications allow section four to answer the question whether quotas for the young can be justified in democracy. Answering this first question enables us to move on in section five to my second question, whether youth quotas can be an effective means to secure environmentally sustainable policy-making.

\section{What Are Quotas and What Can Quotas Achieve?}

The 1970s witnessed a heated debate not only among politicians but also among political theorists about whether and on what grounds quotas can be justified in the job market and the educational system. This question has often been dealt with as if quotas were either a normative goal in themselves or necessary to understand the principle of equality of 
opportunity. ${ }^{5}$ I oppose both these understandings of quotas. ${ }^{6}$ Instead, I argue in this section that quotas can only be understood as a means either to realize equality of opportunity or to serve a goal beyond non-discriminatory selection procedures.

Selection procedures for jobs, educational places, or social positions more generally always discriminate, since from the pool of candidates they select the number of individuals needed to fill the positions in question. According to a formal understanding of equality of opportunity, such discrimination is justified under the condition that only characteristics of candidates who are suitable are considered to fill the position under consideration. In other words, only those characteristics of candidates which enhance the prospect of successful performance of a social position should be taken into account (Sher 1988). All other criteria which might play a role in selecting candidates are a form of unjustified discrimination. Women, for example, are unjustifiably but not explicitly discriminated against by selection procedures which demand that one must have worked without any breaks for the last five years in the company to gain a position in management. This discriminates against all those women who are of child-bearing age. Furthermore, as Mary Anne Warren argues, such selection procedures reinforce social structures which expect women to stay at home and maintain the household (Warren 1977: 245-249).

Understanding equality of opportunity in this way allows us to expect that, if formal equality of opportunity is fully realized for the educational system and the job market then both genders and all different ethnical, religious and other social groups are proportionally represented in all different kinds of social positions. Put differently, assuming that a society can be divided into different social and economic strata to which specific social positions are

\footnotetext{
${ }^{5}$ For a helpful overview of the debate see Rössler 1993.

${ }^{6}$ For a more developed argument to justify my view see Wallimann-Helmer 2013: esp. chap. 2.
} 
attached, then members of all different social groups in a society with full formal equality of opportunity fill positions in proportion to their number in the society as a whole.

Such an understanding of equality of opportunity has been proposed most explicitly by Onora O’Neill. According to her, the fairest selection procedure is a lottery, since in a lottery all have equal chances of success. Thus, to be a fair procedure of selection, equality of opportunity should guarantee equal chances of success in education and the job market (O'Neill 1976: 338). As a consequence, nothing else can result than proportional representation of both genders and all social groups in all social positions attached to the different socio-economic strata of society.

To ensure that such a proportional distribution of social position is the case, O'Neill proposes to reformulate the principle of equality of opportunity more substantially. Equality of opportunity should be understood as demanding that social positions be divided between all social groups of society in a proportional way (O'Neill 1976: 339-340). This understanding of equality of opportunity establishes a first and strongest understanding of quotas: rigid quotas. Rigid quotas demand that educational places and jobs are distributed in a strictly proportional way. Such an understanding of quotas presupposes that unjustified discrimination is in place and that equality of opportunity is only realized if a proportional distribution of social positions on all social strata of society occurs. To make this presupposition more concrete and not to use a probably biased language, it is useful to have a closer look at the famous example of a warrior society introduced by Bernard Williams (1973: 244).

Imagine a society in which high prestige is attached to the status of warrior. Traditionally, these warriors have been selected from certain wealthy families of society but not from the poor majority. Such a procedure of selection is certainly unjustifiably discriminatory against the poor majority if we presume that wealth and membership of a 
certain class of families is irrelevant to performing well as a warrior. It would be more appropriate, Williams suggests, to introduce a competition to test the physical strength of those who want to be warriors. If such a selection procedure is adopted and no explicit or implicit unjustified discrimination against the majority of society occurs, then it is reasonable to assume that after some time the warrior class will consist of members of the wealthy families and of the poor majority in proportion to their number in society.

However, as O’Neill has already noted, there are two difficulties involved in this argument (O'Neill 1976: 339-340). First, it may not necessarily be the case that members of both parts of society have the capacity to develop the equivalent capacities required to be successful in the competition. From an egalitarian point of view, it would certainly be objectionable to depend on wealth, social class, religion or ethnic differences to justify unequal capacity. However, differences in wealth and social circumstances can become relevant for how well people are able to develop their natural talents. A wealthy family can provide better training, equipment and assistance. Social circumstances can be more or less supportive. These are reasons to justify a more substantive understanding of equality of opportunity. But this understanding - most commonly, according to Rawls, called fair equality of opportunity (Rawls 1971: 73-74) - does not justify quotas in a rigid sense. It only denotes the conditions which must be secured for all to have a fair chance of success at the outset of the competition. What must be ensured is that social and economic circumstances do not constrain in any relevant sense the opportunities available to all members of society.

Second, it is not at all clear that the willingness of all members in society to become warriors is distributed evenly over all social groups. There might be a significant proportion of the majority who hold pacifist convictions. If this is the case, members of this social group will neither be motivated to prepare for the competition nor will they necessarily take part unless coerced to do so. Therefore, although it might be the case that fair conditions to 
prepare for the competition are given, if the willingness to become a warrior is unevenly distributed in society, it is very likely that a disproportional distribution of warrior positions will be the result. Only as many members of the majority can be successful as are willing to apply for warrior positions. Since in a liberal order no one would be ready to justify coercion to apply for social positions in higher social and economic strata of society, it seems to be more plausible to propose a less rigid, to wit a weaker form of quotas.

This weaker form of quotas, weak quotas for short, takes into account the fact that the willingness to achieve positions of higher and the highest social and economic strata is unevenly distributed amongst the different social groups in society. But it also assumes that unjustified discrimination against some social groups still occurs. Therefore, it must be ensured that successful applicants from the pool of candidates are proportional to how many individuals have applied from the different social groups in society (Warren 1977: 251-253). To use Williams's example once more, if it is the case that for 120 positions as warriors 80 candidates are from wealthy families and 160 from the poor majority of society apply, then these 120 positions should be divided in a ratio of $1: 2$. Forty warrior positions should be assigned to candidates from wealthier families, and 80 should go to candidates from the poor majority. When such a distribution does not occur, it could be argued that unjustified discrimination is the case.

Thus, this understanding of quotas once again presupposes the occurrence of unjustified discrimination, but it takes for granted that not all members of society are equally willing to apply for warrior positions. Such a justification of quotas, however, faces a further difficulty which would also be faced by rigid quotas. If it is demanded that a strict proportional distribution of positions among successful applicants must be secured, then it might be the case that the positions would have to be assigned to members of a particular social group even if they are not as well qualified to fill the positions as applicants from other 
social groups. This is the problem of reverse discrimination. To ensure a more proportional distribution of positions, a selection procedure would have to unjustifiably discriminate against candidates from those social groups which in the past were unjustifiably advantaged. ${ }^{7}$

This must be judged as an unjustified discrimination, since what becomes relevant to realize the requirements of weak quotas are characteristics which are deemed irrelevant for the successful performance of the position. Discriminating against better qualified candidates in the name of quotas means to take into account characteristics such as gender, ethnicity or religion, which, for example, are not relevant for becoming a warrior. Warriors need to display sufficient physical condition. For physical condition, at least in principle, gender, ethnicity and religion are irrelevant. This holds true, however, only when physical condition is not shaped in a significant sense by these aspects of the candidates' backgrounds. Indeed, it could be argued that gender, ethnicity and perhaps even religious socialization significantly constrain the physical condition of candidates. But if only physical strength is relevant for becoming a warrior, then it becomes difficult to argue that unjustified discrimination occurs even if the distribution of warrior positions is not proportional to the genders, ethnicities and religious groups in the warrior society.

There are two further arguments though to justify quotas which would not be in trouble with this last challenge since they justify quotas with a purpose beyond selection procedures for social positions. First, it can be argued that role models are a suitable means to change discriminatory attitudes in society and to motivate members of disadvantaged social groups to apply for social positions in higher social and economic strata. ${ }^{8}$ According to this argument, quotas are justified to create these role models to reach both projected outcomes. Second, it can be argued that quotas are a justified means to enhance the quality of decisions

\footnotetext{
${ }^{7}$ For two classical texts discussing reverse discrimination see Newton 1973 and Dworkin 1977: $269-288$.

${ }^{8}$ This argument has been made in various forms. The first philosopher stating it was to my knowledge Thomson 1973.
} 
taken in higher ranked social positions. In this sense quotas are understood as a means to improve the economy or society as a whole. ${ }^{9}$ Neither of these arguments, however, necessarily justify rigid or weak quotas, since to be in accordance with these demands it would also be appropriate to select in favour of disadvantaged social groups if they are equally qualified for a social position. This would be a claim for an even weaker form of quotas than those discussed above. For the purpose of this paper I will name it "affirmative action". ${ }^{10}$

Either way, whatever form of quotas we think to be appropriate, I think they can only be justified as a means to overcome unjustifiably discriminatory selection procedures. The main reason for this belief can be found in the presumption I mentioned. For quotas to be justified, more or less explicitly unjustifiably discriminating practices must be in place. If this condition is not given or at least counterfactually presumed, it is not possible to argue for quotas. If a selection procedure is fair and does not display any explicit or hidden form of unjustified discrimination, then whatever distribution occurs must be accepted as fair.

Furthermore, the arguments from role models and an improved economy or society show that quotas are only justified if they arrive at the projected goal. Role models have to be an effective means to change discriminatory attitudes in society and more diversity in higherranked social positions must be shown to be an appropriate means to improve the economy or society. This can certainly be correct, but it is only under these conditions that quotas are justified. And since these arguments take quotas to be a means to reach these ends, they are instruments - but seem not to be normative goals in themselves.

\footnotetext{
${ }^{9}$ One of the recent statements of this argument with regard to education is provided by Anderson 2007.

${ }^{10}$ In calling this weakest form of quotas "affirmative action" I come close to at least some aspects of what Pojman discussed under the label "weak quotas" (Pojman 1998). However, I am also aware that "affirmative action" broadly understood could denote any kind of preferential treatment of disadvantaged social groups which must not necessarily be linked with the idea of quotas.
} 
In addition, arguing for proportional representation of all social groups of society in all different social and economic strata in society presupposes that the willingness to apply for these positions is evenly distributed among all social groups. This makes it necessary to ensure substantial conditions to secure that neither social nor economic differences have a significant impact on how successful members of different social groups are in education and the job market. However, these conditions do not depend on the distributive result but the pre-conditions securing fair preparation for all to be successful. Thus, they cannot justify quotas, but they do justify an understanding of equality of opportunity which also secures these conditions. With these considerations in mind, let us now turn to the question how quotas could become relevant in democracy.

\section{In What Sense Can Quotas Become Relevant in Democracy?}

To see in what sense quotas can become relevant in democracy, it is necessary to be clear about their proper role in such an institutional regime. For this purpose, I think it is helpful not to dig too deeply into different understandings of what democracy is and what institutional framework it demands. I think it is enough to consider a rather formal understanding of democracy and, more specifically, of representative democracy. As we will see in this section, quotas are only appropriate if applied to political institutions and their offices but not to policy decisions themselves. But what is democracy and how can its institutional framework be justified?

To understand what democracy is, it is helpful to introduce the description of democratic government expressed in Lincoln's famous phrase in his Gettysburg address that democracy is "government of the people, by the people, for the people (...)" (Brooks Lapsley 2012). Although it remains unclear in Lincoln's statement who exactly legitimately constitutes the people and on what normative grounds one may be considered part of the 
people, it clarifies how political theorists usually understand democracy. Democracy is an institutional regime in which the whole citizen body, the people of society, governs itself by making and executing decisions and taking responsibility for their consequences in a body.

The liberal Western tradition of political theory has found several different ways of normatively justifying the right to democratic government. What all these theories have in common, however, is the presumption that human beings are and have to be respected as free and equal. To respect human beings as free, their right to liberty cannot be restricted without giving them a say in the political process leading to such restrictions. To respect them as equal, it is necessary to ensure fair chances for all to participate in this decision-making process. How having a say and a fair chance to participate in the decision-making process must be secured is a matter of theoretical dispute. But nowadays, it is almost impossible to defend any political institutional framework without accepting the right of all citizens to be respected as free and equal (Kymlicka 2002: 3f.).

Indeed, to argue for quotas it is necessary to assume a more substantial goal of democracy beyond securing formal conditions of free and equal participation in political decision-making. Without such a more substantial goal it becomes difficult to see what unjustified discrimination in the process of democratic decision-making means. ${ }^{11}$ Thomas Christiano for example suggests, in a democratic regime it must be assured that all human beings are equally respected in their interests. This is only possible if all members of society "on whom the rules [the policy decisions] have a major impact" are equally involved in determining the decision (Christiano 2010: 56). It must be possible for all to participate in

\footnotetext{
${ }^{11}$ To be sure, in democratic theory it is a contested issue whether democracy should be understood only in procedural or also in more substantive terms (e.g. Buchanan 2002; Brettschneider 2005; Christiano 2004; Brettschneider 2005, 2007; van Parijs 2011). In this paper it is not possible to justify the view that genuine democracy should also incorporate a more substantive goal. However, as should become clear in the following a more substantive goal of democracy like the one suggested by Christiano is a necessary presumption in order to make possible an argument for quotas in democracy. I would like to thank Nenad Stojanovic for raising this issue.
} 
political decision-making, and they must be able to see that their interests are respected; what is necessary for policy decisions to be legitimate, therefore, is their public justifiability. Following Christiano, democracy is the best institutional framework to guarantee this condition of public scrutiny, at least partially (Christiano 2004: 275). In this sense then, a democratic institutional order not only secures formal participation in collective decisionmaking for all citizens but also serves the purpose of balancing interests and of avoiding policy-making biased in favour of some interests at the cost of others. Thus, in democracy unjustified discrimination means a tendency for biased decisions in favour of some interests neglecting certain others.

Following on from this, one would expect that, provided the formal conditions to secure free and equal citizenship are present, repeated policy decisions will display the different interests existing in society proportionally. In a society with ten pacifists and five warriors, we expect that every third policy decision will be in favour of the warriors whilst two of the three decisions are in favour of pacifism. However, to argue that quotas for the interests served by policy decisions are appropriate if this is not the case seems to be a misconception of what democracy is. First, although democracy can be viewed as a system to prevent biased policy, it still remains a process of collective decision-making which ideally leads to consent or compromise about what is in the common interest of all members of society. Second, according to Lincoln's description of democracy as "government of the people, by the people, for the people" it must be the citizen body that decides in its own right. Any substantial criteria prescribing in what proportion policy decisions have to display existing interests in society would be in conflict with this description of democracy. According to these two arguments, therefore, it seems to be inappropriate to apply quotas to policy decisions themselves. It is more reasonable to apply them to the composition of political bodies steering a society. 
If it is the composition of the political bodies of democracy to which quotas must be applied, we have to understand in what way it can be justified that only a certain number of citizens fill the relevant offices. I think here it again proves helpful to return to Lincoln's description of democracy as "government of the people, by the people, for the people (...)". According to this statement, policy decisions in a democracy are legitimate only on the condition that it is the whole citizen body that governs in its own right. Whether a model of democracy is a model of direct or representative democracy depends on whether the whole citizen body or only part of it is conceived as necessary to make policy decisions (Christiano 2010: 246). Models of direct democracy argue that the people who should make policy decisions must be coextensive with the whole citizen body. In representative democracy, the assembly making policy decisions can be smaller. Thus, to capture the understanding of representative democracy, Lincoln's phrase needs a slight reformulation: Democracy is government of all the people, by some representatives of the people, for all the people. Representative institutions thus understood are an institutional way to operationalize the process of collective decision-making among all the people so as to make it more efficient and even, according to some views, qualitatively better (e.g. Christiano 2010: 105; Pettit 2004: 60-62; Dobson 1997: 127).

According to this formal description of representative democracy, legitimate representation must take into account all interests present in the citizen body (Dovi 2011; Mansbrige 2003). Furthermore, the members of the legislative assembly must be accountable to the people forming the citizen body since they should decide in the name of the citizen body as whole. In democracy, accountability is usually ensured by election cycles, because these allow those representatives who performed well in representing interests to be reelected and those who performed badly to be deselected (Rehfeld 2006). Thus, representation in democracy can only be legitimate if it is supported by the interests actually present in the 
citizen body. Therefore, the function of the legislative assembly is to represent the interests present in proportion to their weight in the citizen body. The function of an individual representative, by contrast, is to stand or act for those whom he or she represents. This means that, in a society with 1000 pacifists and 500 warriors, an assembly of six individuals would be legitimate if it contained four representatives of the pacifists and two representatives of the warriors. In consequence, it can be argued that in representative democracy unjustified discrimination occurs if such proportional representation of interests is absent or, at least, if certain interests are permanently marginalized.

The legislative assembly is certainly the most obvious institution in a democratic framework to proportionally represent the interests of the citizen body, since in the end all policy decisions must be confirmed by this institution. However, it is not only the legislative assembly which has a major impact on how the interests of the citizen body are taken into account and enforced. Executive, judiciary and administrative bodies also have significant impact. Since the legislative assembly must represent the present interests in society proportionally, and these other institutions have a major impact on how well they are translated into policy, then these institutions would also have to fulfil this representative requirement. But there are two practical reasons why the legislative assembly is not only the most important but also the most plausible political body for which to demand proportional representation of interests. Admittedly, these reasons do not exclude a justification of a proportional representation of interests in executive, judiciary and administrative bodies.

First, with regard to the judiciary and the administrative body, individuals in these offices not only have to be regarded by the citizens to best represent their interests. For successful performance in these offices, other competences are needed. Lawyers need to have sufficient knowledge of jurisprudence; a specific function in the administrative body demands specific qualifications for its fulfilment. Therefore, it would not only be the case 
that those filling these offices have to perform well in representing interests present in the citizen body but must also display the relevant competences. How this necessity of competence should be balanced with the fact that individuals filling these positions should also serve certain interests is a complicated question that I cannot answer here.

Second, there is a different practical difficulty with regard to the executive. Executive offices are not as numerous as seats in the legislative assembly. This makes it difficult to demand that executive organs should represent all interests present in society proportionally. However, if a society is divided into large ethnic, religious, linguistic or geographic groups with conflicting interests, it seems reasonable to argue at least for proportional representation of these groups in society. But this makes it necessary to be clear about the relevance of these groups and their interests. To justify the proportional representation of interests in the executive organs, it has to be shown why the conflicting interests of certain social groups bear such high relevance that the executive should be divided accordingly. This is a central question to be clarified in the next section, in which I try to answer the question whether youth quotas can be justified.

Against the background of the considerations concerning democracy thus far, we can now see in what sense quotas can become relevant in a democracy. They can become relevant to ensure that all interests in the citizen body are represented proportionally. Quotas can be seen as justified means if it becomes apparent that some interests are permanently marginalized within election procedures for the legislative assembly or selection procedures for other offices in other democratic institutions. Such marginalization represents a sort of unjustified discrimination against those holding these interests. However, as we have seen in the last section, this does not mean that quotas are a justified normative goal in themselves. They are only justified as a means to prevent more or less explicit unjustified discrimination in the election and selection procedures for the offices in question. If no such discrimination 
occurs, whatever distribution of offices results must be accepted as legitimate. Furthermore, since in a democracy these procedures are the only way of legitimizing the representation of interests, the resulting distribution of offices has to be accepted as proportionally representing the interests in society.

\section{Can Youth Quotas Be Justified?}

As I have introduced the relevance of quotas in democracy thus far, they are only justified as a means to bring about election and selection procedures which do not unjustifiably discriminate against some interests in society. This makes it necessary that a marginalization of some interests is actually occurring. If this is not the case, then it is not possible to argue for quotas. To assess whether in democracy quotas for the young can be justified to ensure appropriate representation of their interests, we need to deal with another complication. It must be possible to show that the young indeed constitute a relevant social group with specific interests. Otherwise, it becomes difficult to argue for youth quotas as a means to ensure policy-making that is less biased against the young.

In light of Vanhuysse's study, it seems reasonable to argue that the young are marginalized in their interests. In addition, due to demographic development and the conceptual condition that democracies have to be responsive to the interests of the citizen body, it is also reasonable to assume that democracies tend to favour the interests of the old rather than the interests of the young. Both these empirical arguments justify the conclusion that democracies tend to marginalize, to wit unjustifiably discriminate against, the interests of the young. However, this argument only holds under the condition that the young applying for offices are or have unjustifiably been discriminated against in the selection or election procedures for the offices in question. If this were not the case, then quotas as a means to bring about non-discriminatory election or selection procedures could not be justified. 
If this pre-condition is a given, then it is possible to explore further whether and under what conditions youth quotas can be justified. As mentioned above with regard to executive bodies, to argue for quotas for specific social groups in democracy makes it necessary to specify which kinds of social groups can become relevant here. According to the definition of democracy I draw on here, it seems to be unjustifiable to make mere membership of a social group more relevant for the right to proportional representation than the interests present in society potentially crossing the borders of these social groups. In consequence, to argue for proportional representation of social groups rather than the weight of interests present in society it must be possible to show that membership in a social group is a necessary condition for representing the special interests of that social group. Furthermore, it must be the case that a social group is sufficiently homogeneous to be ascribed certain specific interests which are not represented by non-members of these groups. ${ }^{12}$

This challenge is especially pertinent considering the young as a social group. It is not at all clear that being young is a necessary and sufficient condition to have certain specific interests. This for two reasons. First, similar to other social groups divided according to gender, ethnicity, language or geography it is difficult to show that membership in such a group is sufficient to denote certain specific interests. Second, the interests that the young will have will highly depend on their various social, economic, cultural and educational backgrounds. These backgrounds will not necessarily lead to a set of interests shared by all who are young but to various kinds of interests not specifically linked to their age. Therefore, it becomes difficult to argue that being young is a significant condition to represent specific interests.

However, if we take into account that it is not interests by themselves which ground specific political opinions and ideals but the discourses within which one is involved, it is

\footnotetext{
${ }^{12}$ A more developed discussion of this problem can be found in Stojanovic 2013: 133-140.
} 
possible to argue that the young form a social group united enough to justify their proportional representation. John Dryzeck and Simon Niemeyer have argued in this direction (Dryzek und Niemeyer 2008). According to them, what is relevant in democracy is not that interests are proportionally represented but discourses, because discourses are the basis on which interests are formed. Since the young have their own specific discourses, it seems to be plausible that they form a social group that can be represented proportionally. They have their own way to communicate and articulate their hopes and fears, and they consider political challenges their own way. If one argues along these lines, therefore, it becomes possible to view the young as a relevant social group to be represented proportionally. ${ }^{13}$

Once the young or other groups are established as relevant social groups to be represented proportionally, a further difficulty arises. For their representation to be legitimate, to wit not in conflict with Lincoln's description of democracy, social groups can only demand representation in proportion to their weight in the citizen body. Larger social groups or parts of society are entitled to more weight in political bodies than smaller groups. The reason for this is simply that representation of interests in democracy must be proportional to the weight these groups have in society. To argue for more than such proportional representation would need further arguments leading beyond the relevance of quotas in democracy I have argued for thus far. Thus, according to the justification of quotas up to now, quotas to ensure nondiscriminatory selection and election procedures for offices can demand nothing more than the proportional representation of discourses or interests and, if possible to justify, of social groups. This challenge proves to be especially pertinent with regard to quotas for the young, since their plausibility not only stems from the fact that their discourses tend to be marginalized but also because demographic development enforces their marginalization.

\footnotetext{
${ }^{13}$ In addition, an argument along these lines implies that one would have to alter the understanding of democracy and its relevant representative institutions overall. It would not only have to be the discourse of the young which would have to be represented proportionally; it would also have to be all kinds of discourses present in society and not interests.
} 
Quotas as justified thus far cannot solve this problem. This shows why it is especially important to carefully assess which form of quotas would be most appropriate for the young.

With regard to the three different forms of quotas discussed in the second section, it is not at all clear that quotas in democracy should always be rigid. It depends on circumstances and especially on the motivation of members of social groups which form of quotas is appropriate. Rigid quotas are only justified if the groups to be represented proportionally can always nominate enough candidates to effectively fill the positions. If this is not the case, rigid quotas would demand coercive practices for those groups which are not able to nominate enough candidates to conform to the proportional requirement. As in the case for rigid quotas with regard to equality of opportunity, this makes it seem more plausible to propose weak quotas which only demand that the different relevant groups are elected and selected in a proportional way from those applying for offices.

How effective such weak quotas can be to transfer interests into policy, however, depends on the weight of those groups for which proportional representation is ensured by quotas. If a social group does not have enough weight to significantly influence policy decisions, quotas for proportional representation cannot serve the purpose for which they are proposed. Although quotas can serve small minorities to better voice their interests (stemming from their discourses), it is not at all clear that this has a relevant impact on the policy decisions taken. ${ }^{14}$

With these considerations in mind, we see that in certain circumstances political affirmative action programmes and securing substantial assistance for political activity prove more promising than rigid or weak quotas. Political affirmative action programmes would

\footnotetext{
${ }^{14}$ Dryzek and Niemeyer by contrast argue that the frequency with which interests can be and are voiced have a major impact on policy decisions (Dryzek und Niemeyer 2008: 484). If one assumes that voiced beliefs alter political discourse, then - irrespective of the proportion of society minorities constitute - any kind of proportional representation will improve their situation. However, although voicing beliefs can have an impact on the formation of policy decisions when the chips are down, for final decisions the decisive power still lies with the larger social groups and not minorities.
} 
demand that whenever two candidates or parties gain the same or similar votes, the candidate or party belonging to a disadvantaged social group, or proposing more candidates from these groups, is preferred. Substantive assistance, on the other hand, would mean that potentially marginalized social groups are assisted by society in their development of political programmes and financially to be able to voice their views on an equal footing with those interest groups which are economically better situated. ${ }^{15}$ Both measures would not only increase the likelihood that the interests of these minorities are heard; they would also allow these minorities to gain more political influence than they would be proportionally entitled to, since if minorities are able to better voice their beliefs this also increases the likelihood of their political success when applying for offices.

I think - especially for the young - both these kinds of measures will prove the most promising. Political affirmative action programmes will provide incentives for older political leaders and parties to support the young in their political career earlier and with more intensity than they tend to do now. With political affirmative action programmes it becomes interesting for parties to have younger candidates on their lists since that increases the likelihood of being successful in cases in which they have equal or similar citizen support than other parties. Furthermore, if candidates on the lists are elected individually, political affirmative action programmes enhance the chance to gather more seats. In any case in which two candidates, from whatever party they are, gain an equal or similar number of votes, the younger candidate will be given advantage. Substantial assistance for the young, by contrast, would allow the young to politically organize and to campaign for their interests in a way they would not be able to without this help, since it is certainly a fact that older people have more experience in how to organize and have more capital at their disposal for political campaigning.

\footnotetext{
${ }^{15}$ Such a proposal along these lines is for example made by Young 1990.
} 
Taken together, the considerations of this section allow the following conclusions. Quotas for social groups can be justified in democracy if there is marginalization or unjustified discrimination of the specific interests or discourses of these groups. This presupposes that specific interests or discourses and the ability to voice them are sufficiently closely linked with being a member of that social group in question. Against this backdrop, quotas for the young can be justified since the young are obviously discriminated against, and if they in fact constitute a discrete social group. Whether rigid or weak quotas or political affirmative action programmes would better serve the purpose of avoiding the marginalization of the young and other social groups, however, remains a question to be answered depending on the motivation for political action of members of a social group and especially on the kind of social group in question. In case of the young, I suggested, political affirmative action programmes and substantial assistance might prove more effective than rigid or weak quotas.

\section{Are Quotas a Means to Avoid Future Disasters?}

Thus far, I have argued that quotas for the young can be justified, but that it depends on circumstances what form of quotas is appropriate. If enough young people are motivated to engage in politics, then rigid quotas for representative bodies can be justified. To avoid potential coercion to fulfil this proportional requirement, however, it seems more appropriate to propose weak quotas. Furthermore, since due to demographic development the young tend to be outnumbered, it might be better to adopt political affirmative action programmes favouring young candidates whenever they have equal or similar votes to older candidates. These programmes would allow a greater shift in political influence to the young than their number in society. However, whatever form of quotas is adopted, can they ensure that not 
only the interests and discourses of the young are better represented but also that the goal of more long-term policy-making is addressed?

To begin with, there are two obvious reasons to doubt that this question can be answered in the affirmative. First, it is not necessarily membership in a social group that makes individuals better suited to represent particular interests or discourses (Mansbrige 1999: 638). It is not only warriors who can represent the interests of warriors. Pacifists can do the same if they care sufficiently enough for the interest of, say, adequate housing for warriors. And warriors can certainly represent the interests of pacifists if they argue against the duty to become a warrior. Thus, although the concerns Vanhuysse expresses are concerns of the young, it is not at all clear that young citizens will care for them once in office. It is not at all clear that young representatives will represent interests in lower public debt and sustainable policy-making. Young people might be occupied with other things - those things which are relevant to their current situation of life. Therefore, it might be the case that older people will take better care of what is in the long-term interests of the young. This makes it possible to conclude that quotas do not necessarily serve the purpose of ensuring more sustainable policy-making.

Second, as argued in the last section, if quotas only serve the purpose of ensuring proportional representation and outweigh the marginalization of interests or discourses, then greater representation of social groups than their proportion in society cannot be justified. Since due to demographic development the young are increasingly a minority, there is no guarantee that their proportional representation will alter policy decisions in a significant way. This might even be the case if political affirmative action programmes are adopted, because they leave it open to how politics goes whether the young will be successful in transferring their interests into policy. Thus, even though the young might care strongly about 
long-term policy-making, and their proportional representation allows them to better voice their beliefs, it is not a given that quotas will lead to more sustainable policy decisions.

In light of these two arguments, to enhance the capacity of the young to ensure longterm decision-making, it seems more appropriate to bring further arguments to justify quotas in democracy than those provided up to now. Two of these further arguments rely on two justifications of quotas introduced in section two; both leading beyond the goal of ensuring non-discriminatory selection procedures. First, parallel to the argument for role models, it could be argued that quotas could serve the purpose of motivating members of disadvantaged groups to engage more in politics, since once some members of a social group are elected they could serve as role models. If these role models care for sustainable policy-making or lowering public debt, then the young as a group might care more for these questions and influence policy-making accordingly. Second, it could be argued in favour of quotas that more diversity in political bodies enhances the quality of policy decisions, whatever they might be. Third, and going beyond the arguments introduced in section two, it would also be possible to argue that the long-term impacts of policy decisions taken today would be better legitimized if those who have to bear them shared proportional decisive weight.

What we must be clear about in applying these arguments, however, is that they shift the purpose quotas should serve. As I have discussed youth quotas up to now, they have been justified as a means to prevent or avoid marginalization or unjustified discrimination of the young as a social group. In contrast, quotas in these arguments become a means to different ends. Quotas for the sake of role models are a means of achieving more political sensitivity, and if these role models care for long-term interests, then they can enhance awareness of these challenges. In the case of the second argument, quotas are introduced as a means of enhancing the quality of policy decisions. More diversity, it is argued, will lead to more 
creative policy outcomes and to decisions that better mirror what is in the common interest. ${ }^{16}$ Third, better representation of the young can serve as a means to better guarantee the legitimacy of policy decisions and their long-term impacts.

As plausible as these arguments sound by themselves, I do not think that they can justify more than proportional representation of social groups. Whatever purpose role models are able to serve, in democracy quotas are only justifiable up to the point at which positions are filled in relation to the proportion that interests or discourse are present in society. To demand more would mean to subvert the ideal of democracy as I have expressed it in this paper. The same is true with regard to the argument that quotas might help enhance the quality of policy decisions. Although it might be correct that more diversity enhances the quality of policy decisions, demanding more than proportional representation of social groups would once again mean subverting the idea of legitimate representation in democracy. These considerations become especially relevant with regard to the last argument since, if quotas are a means to enhance the legitimacy of the long-term impacts of policy decisions, then they have to be proportional. According to Lincoln's description of democracy, to argue for quotas in any other sense would be illegitimate.

Furthermore, these three additional arguments in favour of quotas also face the second challenge mentioned above. It is not necessarily the case that young role models will care about those interests denoted by Vanhuysse as the interests of the young. And although more diversity might lead to a better quality of policy decisions, it must remain an open question what such better quality would be. In democracy, it must be the citizen body as a whole who should decide what good policy decisions are, since it is the political body which is accountable to itself. Any qualitative criteria prescribing how a society has to decide would be in conflict with the conditions of legitimacy in democracy. Therefore, although

\footnotetext{
${ }^{16}$ For this argument see for example Dryzek und Niemeyer 2008: 484; Young 1990.
} 
proportional representation of the young might enhance the legitimacy of long-term impacts of policy decisions taken today, this does not mean that the decisions must and will further specific and especially long-term goals.

With regard to the last additional argument for quotas, there is at least one reason which only justifies a qualified "No" to answer the second question I have investigated here. Since the long-term consequences of policy decisions have to be borne by today's young, enhancing their legitimacy is important. Those who have to bear these long-term consequences should also have appropriate weight in deciding whether or not to take the risks involved in these decisions. This makes it reasonable to argue that youth quotas are justified because they enhance the legitimacy of long-term policy consequences. But they cannot be justified with regard to any substantial policy goal, such as lowering public debt or sustainability. Once again, whether enhanced legitimacy in this sense is best realized via rigid or weak quotas or via political affirmative action programmes depends on how the motivation for political engagement is distributed among the young. As argued in the last section, with regard to demographic development there is good reason to argue for the last and weakest form of quotas in combination with substantial political assistance for the young. If the young are successful in politics, both these measures would facilitate more than proportional political influence of the young, which would enhance the legitimacy of the long-term impacts of policy decisions taken today.

\section{Conclusion}

In this paper I have argued for four conclusions. First, quotas are not normative goals in themselves but only a means: first and foremost a means to ensure the absence of more or less hidden unjustified discrimination. Second, in democracy quotas are most plausibly used as a means to fill offices in those bodies which have a major impact on how well interests or 
discourses are translated into policy. Quotas for the legislative assembly are therefore most important. Third, quotas for the young can be justified since, due to demographic development, their discourses tend to be marginalized. What form of quotas is most appropriate to serve this purpose remains an open question. It depends on the motivation of the young for political engagement which form best serves their better integration in the political process. I suggested that political affirmative action programmes together with substantial political assistance for the young might prove most promising. Fourth, quotas cannot be justified as a means to ensure long-term policy-making, but they can ensure better legitimacy of the long-term impacts of policy decisions taken today. In the light of challenges such as high pubic debts, environmental disasters and climate change, it is this last argument which best justifies quotas for the young.

\section{Acknowledgements}

This paper has been presented at the academic symposium "Youth Quotas: The Answer to Changes in Age Demographics?" in Stuttgart and at a session of the Chair Hoover's Mardi Intimes (Michs). I would like to warmly thank the audiences of these occasions for very helpful comments on earlier drafts of this paper. My special thanks go to Petter Godli, Axel Gosseries, Anja Karnein, Antony Mason, Tim Meijers, Simon Milligan, Dominic Roser, Nenad Stojanovic, Jörg Tremmel and Philippe van Parijs for very helpful discussions, very much needed feedback and important inspiration. I also would like to acknowledge the generous financial support from Stiftung Mercator Switzerland (http://cms.stiftungmercator.ch) and the University of Zurich's Research Priority Program in Ethics (URPP Ethics) without which the research for this paper would not have been possible.

\section{References}


Anderson, Elizabeth (2007): Fair Opportunity in Education: A Democratic Equality Perspective. In: Ethics 117 (4), 595-622.

Brettschneider, Corey (2005): Balancing Procedures and Outcomes Within Democratic Theory: Core Values and Judicial Review. In: Political Studies 53, 423-441.

Brettschneider, Corey (2007): Democratic Rights. The Substance of Self-Government. Princeton: Princeton University Press.

Brooks Lapsley, Arthur (2012): The Papers and Writings of Abraham Lincoln. Volume Seven. Hg. v. The Project Gutenberg. Online verfügbar unter http://www.gutenberg.org/files/2659/2659-h/2659-h.htm\#link2H_4_0028, zuletzt geprüft am $10 / 31 / 2013$.

Buchanan, Allen (2002): Political Legitimacy and Democracy. In: Ethics 112 (4), 689-719.

Christiano, Thomas (2004): The Authority of Democracy. In: The Journal of Political Philosophy 12 (3), 266-290.

Christiano, Thomas (2010): The Constitution of Equality. Democratic Authority and its Limits. Oxford: Oxford University Press.

Dobson, Andrew (1997): Representative Democracy and the Environment. In: William M. Lafferty und James Meadowcroft (ed.): Democracy and the Environment. Problems and Prospects. Cheltenham, Lyme: Edward Elgar Publishing, 124-139.

Dovi, Suzanne (2011): Political Representation. In: Edward N. Zalta (ed.): Stanford Encyclopedia of Philosophy. Online verfügbar unter http://plato.stanford.edu/archives/win2011/entries/political-representation/, zuletzt geprüft am 10/5/2012.

Dryzek, John S.; Niemeyer, Simon (2008): Discursive Representation. In: Am. Pol. Sci. Rev. 102 (4), 481-493.

Dworkin, Ronald (1977): Taking Rights Seriously: Bloomsbury Publishing.

Dyson, Tim (2012): On Demographic and Democratic Transitions. In: Population and Development Review 38 (Supplement), 83-102.

Ekeli, Kristian Skagen (2005): Giving a Voice to Posterity - Deliberative Democracy and Representation of Future People. In: J Agric Environ Ethics 18 (5), 429-450.

Kymlicka, Will (2002): Contemporary political philosophy. An introduction. 2nd ed. Oxford: Oxford University Press.

Mansbrige, Jane (1999): Should Blacks Represent Blacks and Women Represent Women? A Contingent "Yes". In: The Journal of Politics 61 (3), 628-657.

Mansbrige, Jane (2003): Rethinking Representation. In: American Political Science Review 97 (4), 515-528.

Newton, Lisa H. (1973): Reverse Discrimination as Unjustified. In: Ethics 83 (4). 
O'Neill, Onora (1976): How Do We Know When Opportunities Are Equal? In: Carol C. Gould und Marx W. Wartofsky (ed.): Women and Philosophy. Toward a Theory of Liberation. New York: Putnams, 334-346.

Pettit, Philipp (2004): Depoliticizing Democracy. In: Ratio Juris 17, 52-65.

Pojman, Louis P. (1998): The Case Against Affirmative Action. In: International Journal of Applied Philosophy 12 (1), 97-115.

Rawls, John (1971): A Theory of Justice. Original ed. Cambridge, Mass: Belknap Press.

Rehfeld, Andrew (2006): Towards a General Theory of Political Representation. In: The Journal of Politics 68 (1), 1-21.

Rössler, Beate (1993): Quotierung und Gerechtigkeit: Ein Überblick über die Debatte. In: Beate Rössler (ed.): Quotierung und Gerechtigkeit. Eine moralphilosophische Kontroverse. Frankfurt/Main: Campus-Verl (Theorie und Gesellschaft, 29), 7-28.

Sher, George (1988): Qualifications, Fairness and Desert. In: Norman E. Bowie (ed.): Equal Opportunity. Boulder, Colorado: Westview Press, 113-127.

Stojanovic, Nenad (2013): Dialogue sur les quotas. Penser la représentation dans une démocratie multiculturelle. Paris: Presses de Sciences Po.

Thompson, Dennis F. (2010): Representing Future Generations: Political Presentism and Democratic Trusteeship. In: Critical Review of International Social and Political Philosophy 13 (1), 17-37.

Thomson, Judith Jarvis (1973): Preferential Hiring. In: Philosophy \& Public Affairs 2 (4), 364-384.

van Parijs, Philippe (1998): The Disfranchisement of the Elderly, and Other Attempts to Secure Intergenerational Justice. In: Philosophy and Public Affairs 27 (4), 292-333.

van Parijs, Philippe (2011): Just Democracy. The Rawls-Machiavelli Programme. London: ECPR Press (ECPR Press essays).

Vanhuysse, Pieter (2013): Intergenerational Justice in Aging Societies. A Cross-national Comparison of 29 OECD Countries. Online verfügbar unter http:/www.sginetwork.org/pdf/Intergenerational_Justice_OECD.pdf, zuletzt geprüft am 11/1/2013.

Wallimann-Helmer, Ivo (2013): Chancengleichheit im Liberalismus. Bedeutung und Funktion eines überschätzten Ideals. Diss. Univ. Zürich, 2010. - Ref.: Anton Leist, Georg Kohler. Freiburg: Alber (Band 51).

Warren, Mary Anne (1977): Secondary Sexism and Quota Hiring. In: Philosophy \& Public Affairs 6 (3), 240-261.

Williams, Bernard (1973): The Idea of Equality. In: Bernard Williams (ed.): Problems of the Self. Cambridge: Cambridge University Press, 230-249.

Young, Iris Marion (1990): Justice and the Politics of Difference. Princeton, N.J: Princeton University Press. 